\title{
Production of Axenic Cultures of Soil-borne and Endophytic Blue-green Algae
}

\author{
By J. W. BOWYER AND V. B. D. SKERMAN \\ Department of Microbiology, University of Queensland, \\ Medical School, Herston, Brisbane, Queensland, Australia
}

(Accepted for publication Io June 1968)

\begin{abstract}
SUMMARY
A relatively rapid and reliable method is described for producing axenic cultures of soil-borne blue-green algae, of the blue-green algal endophytes of certain cycads, and the blue-green endophyte of the angiosperm Gunnera chilensis Endl. It was based on the micro-manipulation of hormogonia and akinetes, from which axenic cultures were propagated. Micromanipulation was done during growth in impure culture on an agar medium. The technique was used to obtain axenic cultures of fifteen soil isolates, the endophytes of the cycads Macrozamia lucida (Linnaeus) Johnson, Encephalartos altensteinii Lehm., and Bowenia serrulata Bull, and the endophyte of Gunnera chilensis Endl. The soil isolates have been tentatively identified as species of the genera Nostoc, Anabaena, Calothrix, Scytonema, Wollea, Microchaete, and Oscillatoria.
\end{abstract}

\section{INTRODUCTION}

The blue-green algae have been found exceptionally difficult to obtain in axenic (pure) culture, due largely to their characteristic mucilaginous sheaths which harbour contaminating bacteria (Fritsch, 1945; Pringsheim, 1946). Thus protected, the bacteria are virtually impossible to eliminate by standard microbiological plating and dilution techniques. A variety of approaches has been tried for producing axenic cultures, but in all instances they have involved trial and error techniques, very dependent upon the chance removal of microbial contaminants.

Ultra violet (u.v.) irradiation, to which blue-green algae have been found relatively resistant, has been the most widely used method for obtaining axenic cultures (Allison \& Morris, 1930; Allison, Hoover \& Morris, 1937; Gerloff, Fitzgerald \& Skoog, 1950; Fogg, 1951; Holm-Hansen, Gerloff \& Skoog, 1954; Venkataraman, Dutta \& Natarajan, I959; Venkataraman, 196I; 1962). Kraus (1966) produced axenic cultures by the use of gamma radiation, to which blue-green algae were also found to be relatively resistant. Other techniques which have been used include: (a) repeated sub-culture on a silica gel + mineral salts medium (De, 1939; Fogg, 1942, 1944; Henriksson, 195I; Watanabe, 195I); (b) methods based on phototactic and migration responses of blue-green algae (Schramm, I9I4; Allen, 1952; Bunt, 196I); (c) use of antibiotics, successfully for one species by Pintner \& Provasoli (I958), but found to be of no value by Tchan \& Gould (I96I); $(d)$ use of disinfectants such as dilute chlorine water (Fogg, 1942, one species) and dilute phenol solution (McDaniel, Middlebrook \& Bowman, 1962, one species); (e) treatment of one species at a pressure of $12,000 \mathrm{lb}$./sq. inch, which destroyed bacteria and fungi, but had relatively little 
destructive effect on the alga (Middlebrook \& Bowman, I964); $(f)$ relation of the problem to a binomial distribution function, and resultant use of a very laborious method based on dilution and replication (Tischer, 1965; two species). That chance plays a major role in these techniques is illustrated by the fact that Stewart (1962), who used a combination of radiation, antibiotic and plating methods, obtained an axenic culture of Oscillatoria only after 17 months. Further, the use of u.v. or gamma radiation may be criticized on the grounds of their possible mutagenic effects. Kumar (1963) and Singh \& Singh (1964) produced strains of blue-green algae resistant to u.v. radiation, the use of which could conceivably lead to the selection of an axenic mutant of the original organism to be purified.

For these reasons, a method was sought which would enable the direct selection of uncontaminated algal material, from which axenic cultures could be propagated. The obvious approach was the use of a micromanipulator. This was tried by Gerloff et al. (1950), who were able to isolate only one species. Watanabe \& Kiyohara (1963), who used a micromanipulator and antibiotic-containing media, were able to purify only 7 of 14 isolates from various lichens, liverworts and cycads. However, in neither instance were details of the micromanipulative procedures given.

The technique to be described was developed as a result of the necessity to obtain axenic cultures for the study of nitrogen fixation by blue-green algae. The micromanipulator used throughout the work was developed by Skerman (I968).

\section{METHODS}

In outline, the isolation technique involved growth of the impure algae on a mineral salts-agar medium, from which uncontaminated material was selected by micromanipulation, then transferred to a silica gel medium, in which the axenic cultures developed.

The medium used was like that described by Allen \& Arnon (1955), except that the elements of their medium not yet shown to be required for growth were omitted. The formula was: macronutrients (g./l. glass distilled water) $\mathrm{MgSO}_{4} \cdot 7 \mathrm{H}_{2} \mathrm{O}, 0.25$; $\mathrm{K}_{2} \mathrm{HPO}_{4}, 0.2 ; \mathrm{CaCl}_{2}, 0.056 ; \mathrm{KNO}_{3}, 0.5 ;$ micronutrients (mg./l.) (the metal equivalents, in mg./l., are given in parentheses) ferric monosodium salt of EDTA, 33.0 $\left(\mathrm{Fe}=5^{\circ} 0\right)$; $\mathrm{MnCl}_{2} \cdot 4 \mathrm{H}_{2} \mathrm{O}, \mathrm{I} \cdot 8 \mathrm{I}(0.5) ; \mathrm{Na}_{2} \mathrm{MoO}_{4} \cdot 2 \mathrm{H}_{2} \mathrm{O}, \mathrm{I} \cdot 469$ (0. I); $\mathrm{ZnSO}_{4} \cdot 7 \mathrm{H}_{2} \mathrm{O}, 0.222$ (0.05); $\mathrm{CuSO}_{4} \cdot 5 \mathrm{H}_{2} \mathrm{O}, 0.079(0.02) ; \mathrm{H}_{3} \mathrm{BO}_{3}, 2.86(0.5) ; \mathrm{Co}\left(\mathrm{NO}_{3}\right)_{2} .6 \mathrm{H}_{2} \mathrm{O}, 0.049$ (0.0I). Analytical grade chemicals were used. For solid media in early experiments, Difco Bacto agar was added at $\mathrm{I} \cdot 5 \%(\mathrm{w} / \mathrm{v})$. Oxoid Ion agar No. 2 was later substituted at $\mathrm{I} \cdot 3 \%$ $(\mathrm{w} / \mathrm{v})$. The medium was adjusted to $\mathrm{pH} 7 \cdot 5$, and it was sterilized at $12 \mathrm{I}^{\circ}$ for $\mathrm{I} 5 \mathrm{~min}$. The silica gel medium was prepared in $20 \mathrm{ml}$. quantities in screw-capped bottles or in Petri dishes, by mixing equal volumes of the above mineral salts solution prepared at double concentration, and $3.0 \%(\mathrm{w} / \mathrm{v})$, silicic acid, prepared according to the method of Pramer (1957). Tap-water agar was prepared by dissolving $15 \mathrm{~g}$. of Difco Bacto agar in $\mathrm{I}$ 1. tap water, and autoclaving at $121^{\circ}$ for $15 \mathrm{~min}$.

\section{Isolation procedures}

(i) Primary isolation from soil. Soil was collected in sterile screw-capped bottles from the surface half-inch of a Black Earth under fallow (Darling Downs, Queensland), by aseptic technique. In an attempt to select nitrogen-fixing species, I $g$. soil was 
added to $10 \mathrm{ml}$. liquid medium, lacking combined nitrogen, in $50 \mathrm{ml}$. Erlenmeyer flasks, which were incubated under continuous fluorescent light of 800 lux intensity at the level of the cultures, at $25-30^{\circ}$. After 3 to 4 weeks some flasks developed dense growths of filamentous blue-green algae, which were then subjected to purification procedures.

(ii) Primary isolation of endophytes. Pieces of alga-containing cycad coralloid roots were surface-sterilized by immersion in $70 \%(\mathrm{v} / \mathrm{v})$ ethanol in water for $\mathrm{I}$ min., then in $10 \%(\mathrm{w} / \mathrm{v})$ sodium hypochlorite solution for $5 \mathrm{~min}$., followed by repeated washing with sterile distilled water. Sections about $\mathrm{I} \mathrm{mm}$. thick were cut with a sterile scalpel and placed on the silica gel medium in Petri dishes.

Pieces of stem tissue containing the endophyte of Gunnera chilensis were surfacesterilized as above. The algal mass was then dissected out as aseptically as possible, and plated in small fragments onto silica gel medium. Plates were incubated under continuous fluorescent light, as with the soil flasks. Colonies of blue-green algae developed as concentric rings around the coralloid root sections and the Gunnera tissue in 3 to 5 weeks (Pl. I, fig. I-3).

After primary isolations, the procedures for purification of both the soil and endophytic species were the same. The soil cultures in particular were very crude, fungi and amoebae being the principal contaminants, with large numbers of bacteria. Fungi and amoebae were absent from many of the endophytic isolations, presumably as a result of the initial surface sterilization of the host material. When inoculated onto the agar medium, the crude soil isolates were frequently overgrown by fungi and/or amoebae. For this reason cultures free from the latter organisms were first obtained, before attempting to obtain bacteria-free cultures, as follows.

Small pieces of crude algal growth were inoculated onto agar plates, and incubated under continuous illumination for $\mathrm{r}$ to 2 days, by which time fungal and amoeboid contamination had developed. By using a microprobe, and $\times$ Io phase-contrast objective, as large an area of peripheral algal growth as possible was marked out, disregarding bacterial contamination, but taking care to exclude fungi and amoebae. The agar blocks were cut out with a fine sterile scalpel under a stereoscopic microscope, and transferred to glass culture vessels $(3 \mathrm{ml}$. capacity). These vessels were made by cutting $22 \mathrm{~mm}$.-diameter flat bottomed tubes to I I mm. in height, so that they just fitted between the base and lid of a plastic Petri dish. Three such cups were set in each dish in $15 \mathrm{ml}$. of tap-water agar. A few drops of liquid culture medium were added to each cup, so that the algal growth on the surfaces of the agar blocks was just submerged. A pellicle of algal growth usually developed on the liquid surface after Io to I4 days under continuous illumination of 800 lux. This growth was then used for producing bacteria-free cultures, the details of which are as follows.

Petri dishes of agar medium were dried for $2 \mathrm{hr}$ in a $28^{\circ}$ incubator before inoculation. This removed surface moisture and helped to prevent spreading of the bacteria in the algal inoculum. Three small fragments (pin-head size) of inoculum were then placed equidistant apart on the agar surface, and about $25 \mathrm{~mm}$. from the edge of the dish. To help further in preventing the spread of bacteria during inoculation it was found advantageous to inoculate by inverting the plate, and to bring the inoculum up from beneath, so that the surface was touched very lightly, and 'squashing' of the agar was thus minimized.

The inverted plates were incubated under continuous illumination at $25-30^{\circ}$ until 
hormogone migration occurred. Advantage was then taken of the fact that some hormogonia, devoid of the mucilaginous sheaths characteristic of older trichomes, had glided sufficiently far to free themselves from epiphytic bacteria. Hormogonia which glided slowly, or moved only a short distance from the inoculum, were followed by bacteria, from which they were unable to free themselves (Pl. 2, fig. 4, 5, 6). The next stage was the selection of uncontaminated hormogonia by micromanipulation.

Initially, clean hormogonia were selected under the phase-contrast microscope, picked up from the agar surface by a microloop, and transferred to fresh plates of the same agar medium. They invariably failed to grow; possible reasons for this will be discussed later. To eliminate direct manipulation of the hormogonia, uncontaminated ones were selected and a small square of clean agar circumscribed about them by means of a microprobe. The size of the squares varied according to the degree of spreading of the contaminating bacteria, but was usually about I-2 mm. square (Pl. 2, fig. 6). By using an iridotomy knife (a very fine scalpel with a $5 \mathrm{~mm}$. curved blade) the small agar blocks were then dissected out under a stereo microscope, and inverted onto fresh agar. Again the hormogonia failed to grow. Next, the blocks were transferred to the small cups with liquid medium, as described previously for preliminary purification, but again without success. Finally, blocks were prepared as before, and transferred to tubes of silica gel medium. After incubation under continuous illumination, algal growth appeared in most of the tubes after I-2 weeks.

One of the soil isolates was an Anabaena species, whose hormogonia glided over the agar very slowly, and thus did not free themselves from contaminating bacteria. At a certain stage in its developmental cycle the organism produced akinetes (spores), which became detached from the parent filament. By using a microloop with a diameter slightly greater than that of the akinetes (about $20 \mu$ ), the latter were transferred to silica gel medium, on which they germinated after 4 to 6 weeks. Before transfer they were freed from bacteria by gently gliding the microloop over clean areas of the original plate. Under phase contrast there was no problem in deciding whether or not all the bacteria had been removed.

Another Anabaena species was isolated from vegetative material. The bacteriafree terminal regions of some long radiating filaments were cut off with a microprobe, then freed from bacteria by gliding them over a clean agar surface with a microloop. They were then transferred to silica gel tubes by the agar block method described previously, and growth became visible after 3 weeks. However, only a small proportion of the filaments thus isolated grew.

As a test for contamination, samples of growth from the silica tubes were streaked on the algal agar medium, incubated under light for 5 days, and examined under phase contrast. As a further test, peptone + yeast-extract (both agar and liquid media), Jensen dextrin agar for Azotobacter, and Brewer medium for anaerobes, were inoculated with algal samples. After incubation at $28^{\circ}$ and $37^{\circ}$ for 5 days, the plates were examined under phase contrast. These tests revealed a few cases of contamination, probable reasons for which will be discussed later.

\section{RESULTS}

Thirteen species, isolated from a Black Earth soil, were obtained in axenic culture by the methods described. They have been tentatively identified as three species of 
the genus Nostoc, two each of Calothrix, Scytonema, and Microchaete, one each of Wollea and Oscillatoria (all isolated from hormogonia), one species of Anabaena isolated from akinetes, and another species of Anabaena derived from filament fragments. In addition, axenic cultures of Nostoc muscorum and Oscillatoria amoena, from the Departmental culture collection, were obtained from hormogonia. Axenic cultures of the endophytes of the cycads Macrozamia lucida (Linnaeus) Johnson, Encephalartos altensteinii Lehm., and Bowenia serrulata Bull, and the endophyte of the angiosperm Gunnera chilensis Endl., were also derived from hormogonia.

The anatomy of the coralloid roots of Macrozamia communis L. Johnson was described in detail by Wittmann, Bergersen \& Kennedy (I965), but they were unable to obtain an axenic culture of the agal endophyte. The present report appears to be the first time that the endophyte of Bowenia serrulata has been isolated. This genus is endemic to Australia (Johnson, 1959). Spratt (I915) examined the roots of B. serrulata plants growing in Kew Gardens, but she found no alga-containing coralloid roots.

The endophytes of the cycads and of the genus Gunnera have been variously identified as species of Nostoc or Anabaena (Spratt, 1915; Winter, 1935; Schaede, I95I; Douin, 1953; Watanabe \& Kiyohara, 1963). The filamentous characteristic of aggregating into definite colonies in culture, as observed in the present study (P1. 2, fig. 4), would suggest that the endophytes belong to the genus Nostoc. The filaments of Anabaena do not form such colonies (Prescott, 1964).

The four endophytes and twelve of the thirteen soil isolates have all been maintained through numerous sub-cultures in nitrogen-free liquid medium. This suggests they are capable of fixing nitrogen. The species of Oscillatoria requires combined nitrogen for growth.

\section{DISCUSSION}

The origin of the occasional contamination of cultures developed from initially pure material seems to lie in the transfer of the agar blocks. In some cases the hormogonia migrated only a small distance (a few $\mathrm{mm}$.) from the parent inoculum, so that unless the agar blocks came away cleanly during removal, their edges could become contaminated by bacteria on the adjacent agar surface. This problem was minimized by pouring a thin layer of medium over a basal layer which had been allowed to set for several hours; the thin layer was more easily removed, since it eliminated breaking of the small blocks.

Migration of hormogonia on the silica gel medium was superior to that on agar, but its use for primary isolation purposes was impractical, because of its characteristic water of syneresis, which allowed bacteria to spread over the entire plate. For this reason, the relatively hard $\mathrm{I} \cdot 5 \%$ agar (Difco) was used. Hormogonium production and migration seemed to be better on Oxoid Ion agar No. 2, as compared with that on the Difco product; it was therefore used throughout the latter part of the work. The very firm gel produced at $\mathrm{I} \cdot 3 \%$ (w/v) Ion agar No. 2 did not inhibit migration, and greatly facilitated the removal of the agar blocks.

It is not clear why transferred hormogonia did not grow on agar media, but grew very successfully on silica gel. This phenomenon has also been encountered by Professor G. E. Fogg (personal communication). It seemed possible that insufficient free moisture is available from firm agar gels, but growth could not be induced even when the agar concentration was decreased to $0.3 \%$, which gave a very soft medium 
just sufficiently firm to support the small agar blocks. That agar itself is toxic seems very unlikely, since hormogonia migrating on agar plates develop into colonies quite satisfactorily when not transferred, and cultures transferred from silica gel to agar develop normally, provided inocula of macroscopic size are used. The possibility that developing hormogonia require some diffusible substance from the parent colony also seems unlikely, since any such factor would be eliminated when the agar blocks are transferred to silica gel.

The failure of hormogonia to grow when transferred directly in microloops is possibly due to osmotic damage caused by rapid drying of the moisture film on the loop during the transfer. This supposition is supported by the fact that hormogonia which are floated in a water film across the agar may survive and even multiply, for several days; but they too eventually die. Perhaps the hormogonia suffer mechanical damage during manipulation, since they are observed to disintegrate within a few hours to several days of such treatment. It may be significant that akinetes were not damaged during transfer, possibly as a result of their thickened walls, and consequent ability to withstand desiccation and mechanical injury.

There was never any doubt about the purity of the migrating hormogonia. Under the phase-contrast microscope, bacteria could be seen along the slime tracks produced by the hormogonia, some of which eventually out-stripped the bacteria. Slow moving hormogonia were unable to free themselves from bacteria, which remained as a mantle about the algal filament (P1. 2, fig. 5). The outstanding advantage of the method described is that, by direct microscopic selection of pure algal material, the factor of chance is practically eliminated, and arises only occasionally through contamination during the second stage of the transfer process. Such contamination is readily detected. A further advantage lies in the time factor, since axenic cultures can be developed within a few weeks, and the large number of successive transfers involved in other techniques is eliminated.

We wish to express sincere thanks to Mr H. C. Caulfield, Curator of the Botanic Gardens, Brisbane, for providing material of Gunnera chilensis and Encephalartos altensteinii; to Mr P. Gordon, Forestry Officer at Byfield, Q., for Bowenia serrulata, and to Dr A. W. Moore, C.S.I.R.O. Cunningham Laboratory, for Macrozamia lucida. Thanks are due to Mr G. Jurott, Dept. of Clinical Photography, University of Queensland, for the photographic work. The work was supported by a grant from the Rural Credits Department of the Reserve Bank of Australia.

\section{REFERENCES}

Allen, Mary B. (1952). The cultivation of Myxophyceae. Arch. Mikrobiol. 17, 34.

Allen, Mary B. \& ARnon, D. I. (1955). Studies on nitrogen-fixing blue-green algae. I. Growth and nitrogen fixation by Anabaena cylindrica Lemm. Plant Physiol. 30, 366.

Allison, F. E. \& Morris, H. J. (1930). Nitrogen fixation by blue-green algae. Science, N. Y. 71, 221.

Allison, F. E., Hoover, S. R. \& Morris, H. J. (1937). Physiological studies with the nitrogen-fixing alga Nostoc muscorum. Bot. Gaz. 98, 433.

BUNT, J. S. (1961). Isolation of bacteria-free cultures from hormogone producing blue-green algae. Nature, Lond. 192, 1275.

DE P. K. (1939). The role of blue-green algae in nitrogen fixation in rice fields. Proc. R. Soc. B, 127, 121 .

Douin, R. (1953). Sur la fixation de l'azote libre par les Myxophyces endophytes des Cycadacees. C. r. Séanc. Acad. : aris 236, 956. 
FoGG, G. E. (1942). Studies on nitrogen fixation by blue-green algae. I. Nitrogen fixation by Anabaena cylindrica Lemm. J. exp. Biol. 19, 78.

Fogg, G. E. (1944). Growth and heterocyst production in Anabaena cylindrica Lemm. New Phytol. 43,164 .

FogG, G. E. (195I). Studies on nitrogen fixation by blue-green algae. II. Nitrogen fixation by Mastigocladus laminosus Cohn. J. exp. Bot. 2, 117.

FrIrsch, F. E. (1945). The Structure and Reproduction of the Algae, vol. 2. Cambridge University Press.

Gerloff, G. C., Fitzgerald, G. P. \& Skoog, F. (1950). The isolation, purification, and culture of blue-green algae. Am. J. Bot. 37, 216.

Henriksson, E. (195I). Nitrogen fixation by a bacteria-free, symbiotic Nostoc strain isolated from Collema. Physiologia Pl. IV, 542.

Holm-Hansen, O., Gerloff, G. C. \& Skoog, F. (1954). Cobalt as an essential element for blue-green algae. Physiologia Pl. 7, 665 .

Jornson, L. A. S. (1959). The families of cycads and the Zamiaceae of Australia. Proc. Linn. Soc. N.S.W. 84, 64.

KraUS, M. P. (1966). Preparation of pure blue-green algae. Nature, Lond. 21 r, 3 Io.

KumaR, H. D. (1963). Effects of radiations on blue-green algae. I. The production and charac. terization of a strain of Anacystis nidulans resistant to u-v radiation. Ann. Bot. 27, 723 .

McDaniel, H. R., Middlebrook, J. B. \& Bowman, R. O. (1962). Isolation of pure cultures of algae from contaminated cultures. Appl. Microbiol. ro, 223.

Middlebrook, J. B. \& Bowman, R. O. (1964). Preparation of axenic cultures of algae by use of a French press. Appl. Microbiol. 12, 44.

Pintner, I. J. \& Provasoli, L. (1958). Artificial cultivation of a red pigmented marine blue-green alga, Phormidium persicinum. J. gen. Microbiol. 18, 190.

Pramer, D. (1957). The influence of physical and chemical factors on the preparation of silica gel media. Appl. Microbiol. 5, 392.

Prescotr, G. W. (1964). How to Know the Fresh-water Algae. Iowa: Wm. C. Brown Co. Publishers.

Pringsheim, E. G. (1946). Pure Cultures of Algae. Cambridge University Press.

SCHAEDE, R. (I95I). Über die Blaualgensymbiose von Gunnera. Planta 39, I 54.

Schramm, J. R. (1914). Some pure culture methods in the algae. Ann. Mo. bot. Gdn. r, 23.

Singh, R. N. \& SiNGH, H. N. (1964). Ultra-violet induced mutants of blue-green algae. I. Anabaena cycadeae Reinke. Arch. Mikrobiol. 48, 109.

Skerman, V. B. D. (I968). A new type of micromanipulator and microforge. J. gen. Microbiol. 53, 287.

Spratt, Ethel R. (1915). The root nodules of the Cycadaceae. Ann. Bot. 29, 6ig.

Stewart, W. D. P. (1962). Fixation of elemental nitrogen by marine blue-green algae. Ann. Bot. 26, 439.

TCHAN, Y. T. \& Gould, J. (196I). Use of antibiotics to purify blue-green algae. Nature, Lond. 192, 1276.

Tischer, R. G. (1965). Pure culture of Anabaena flos-aquae. Nature, Lond. 205, 419.

Venkataraman, G. S. (1961). Nitrogen fixation by Stigonema dendroideum. Indian J. agric. Sci. 31, 213.

Venkataraman, G. S. (1962). Studies on nitrogen fixation by blue-green algae. III. Nitrogen fixation by Anabaena azollae. Indian J. agric. Sci. 32, 22.

Venkataraman, G. S., Dutta, N. \& Natarajan, K. V. (1959). Studies on nitrogen fixation by blue-green algae. I. Nitrogen fixation by Cylindrospermum sphaerica Prasad. J. Indian bot. Soc. 38, I 14.

Watanabe, A. (195I). Production in cultural solution of some amino acids by the atmospheric nitrogen fixing blue-green algae. Arch. Biochem. Biophys. 34, 50.

Watanabe, A. \& Kryohara, T. (1963). Symbiotic blue-green algae of lichens, liverworts, and cycads. In: Studies of Microalgae and Photosynthetic Bacteria. Tokyo University Press. 189.

WINTER, G. (1935). Über die Assimilation des Luftstickstoffs durch endophytische Blaualgen. Beitr. Biol. Pfl. 23, 295.

Wittmann, W., Bergersen, F. J. \& Kennedy, G. S. (1965). The coralloid roots of Macrozamia communis L. Johnson. Aust. J. biol. Sci. 18, 1129.

20

G. Microb. 54 


\section{EXPLANATION OF PLATES}

Plate I

Fig. I. Section of a coralloid root of the cycad Bowenia serrulata, 25 days after inoculation onto silica gel, showing the 'algal zone' (AZ), and algal colonies (AC) developing around the periphery. The Petri dish was incubated at $25-30^{\circ}$ under continuous fluorescent illumination of 800 lux intensity. $\times$ IO.

Fig. 2. The coralloid root section (RS) seen in fig. I, 63 days after inoculation, showing the development of extensive algal growth (A). The piece from the top left corner had been removed as inoculum for purification. $\times 5$.

Fig. 3. Stem tissue (S) containing the endophyte of Gunnera chilensis, from which hormogonia have migrated on the silica gel medium, to produce the radial arrangement of algal colonies (AC); 25 days after inoculation, incubated at $25-30^{\circ}$ under continuous fluorescent illumination of 800 lux intensity. $\times 10$.

\section{Plate 2}

Fig. 4. The endophyte of Bowenia serrulata, growing on mineral salts agar. Note the numerous gliding hormogonia $(\mathrm{H})$, some of which have developed into filaments forming well-defined colonies (C). $\times 100$.

Fig. 5. Hormogonium of a Nostoc soil isolate, gliding on mineral salts agar. This one had glided only a short distance and had not freed itself of contaminating bacteria (B), which remain as an enveloping mantle. Phase contrast. $\times 250$.

Fig. 6. Two uncontaminated hormogonia of the endophyte of Gunnera chilensis, gliding on mineral salts agar. Note the 'slime track' (ST) left on the agar surface. The bordering lines (BL) were marked out with a microprobe, attached to the micromanipulator, and the agar block so defined is ready for transfer. Phase contrast. $\times 100$. 


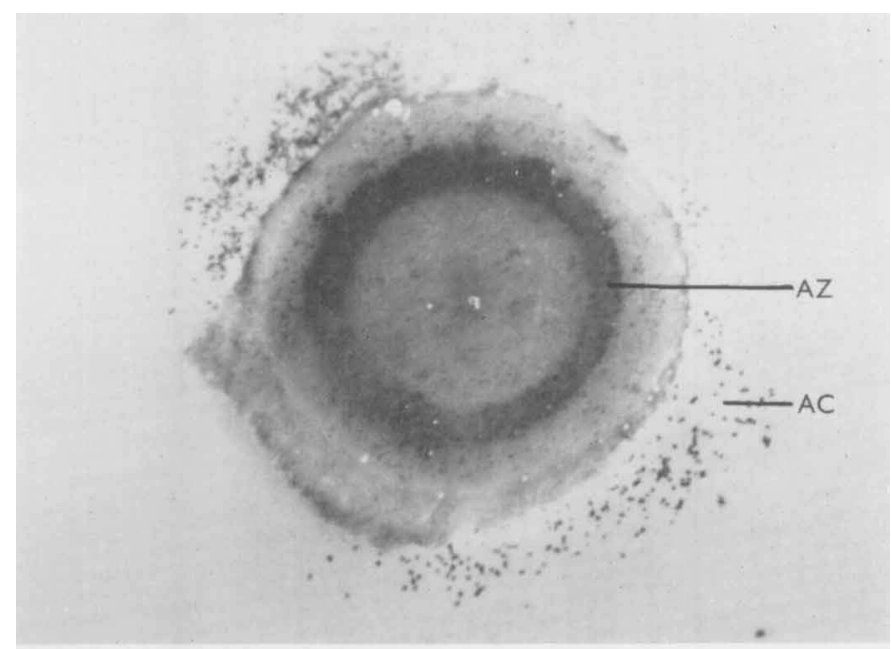

Fig. I

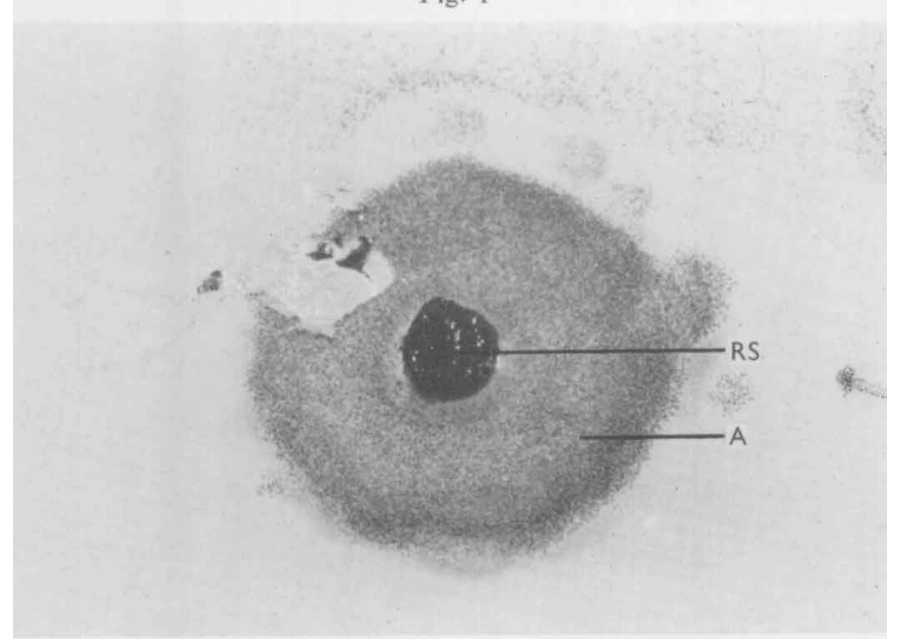

Fig. 2

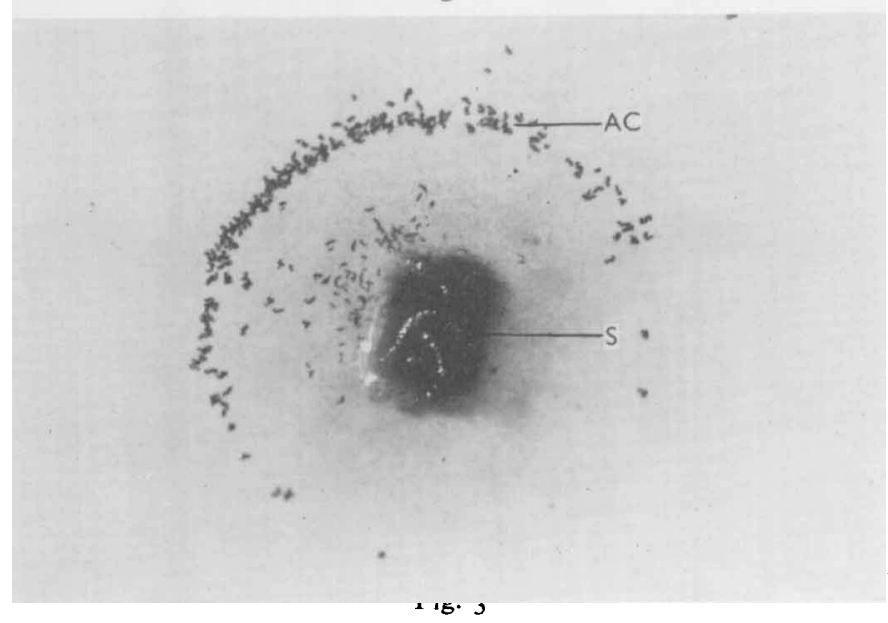


Journal of General Microbiology, Vol. 54, No. 2

Plate 2

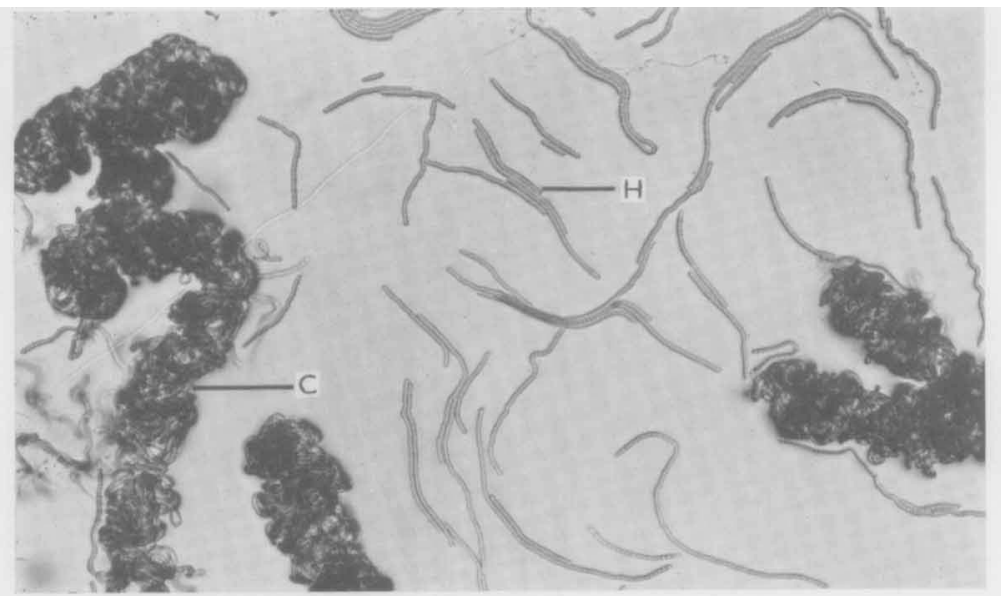

Fig. 4

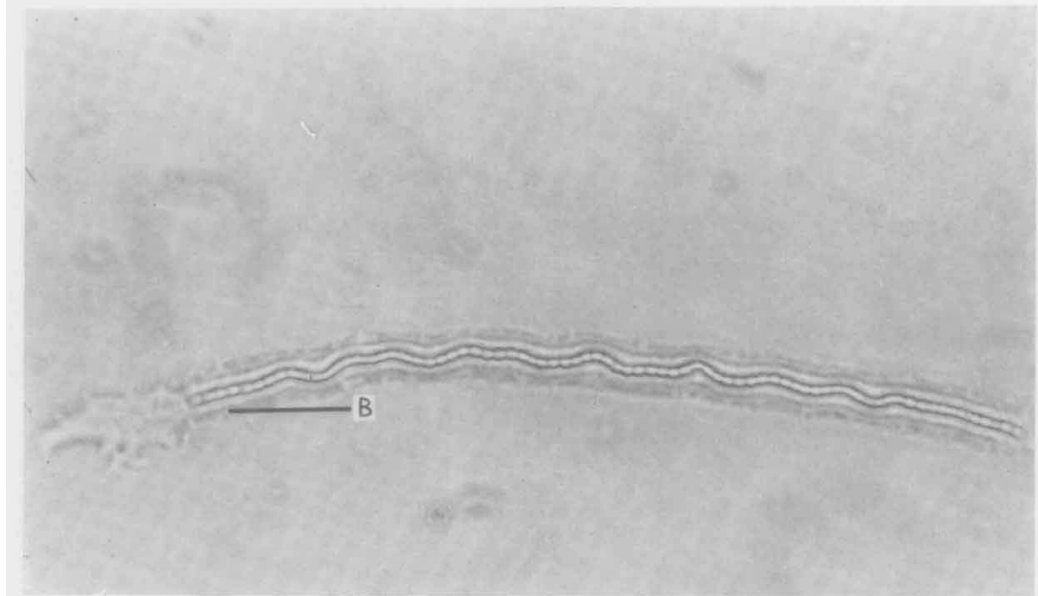

Fig. 5

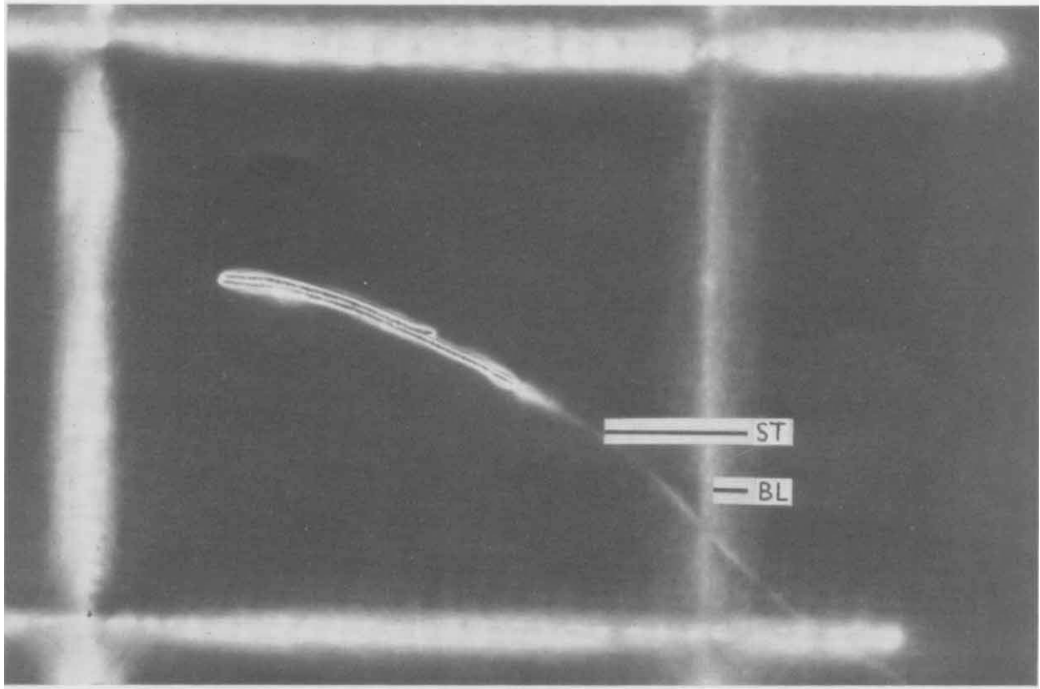

Fig. 6

J. W. BOWYER AND V. B. D. SKERMAN 